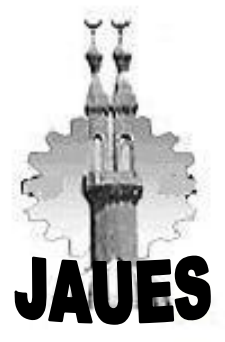

Journal of Al-Azhar University Engineering Sector

Vol.16, No,61, October 2021,1056-1075

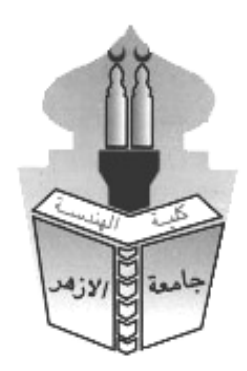

\title{
BEHAVIOR OF HIGH STRENGTH CONCRETE BEAMS REINFORCED WITH (GFRP) BARS
}

\author{
Mohamed Hamdy Elnagar ${ }^{1}$ *, El-Sayed Abdel Raouf ${ }^{2}$, Saeed Ahmed Hasanine ${ }^{3}$, Mohamed Nooman ${ }^{4}$ \\ 1,3,4 Civil Engineering Department, Faculty of Engineering, Al-Azhar University, Cairo, Egypt. \\ ${ }^{2}$ Civil Engineering Department, Faculty of Engineering, Ain Shams University, Cairo, Egypt. \\ *Corresponding Author E-mail: e.moh_ham@yahoo.com
}

\begin{abstract}
The search for a non-corrosion alternative for steel reinforcement expands daily, especially in construction exposed to chemical attacks such as carbonation in aggressive environmental conditions. Glass Fiber Reinforced Polymer (GFRP) bars have become a pioneer in alternatives because of its many advantages such as high tensile strength, lightweight and corrosion-resistant characteristics. In this research, the cracking loads, ultimate loads, crack propagation behavior, load-deflection curves, and the damage to beams were observed at the failure stage for high strength concrete beams (HSCBs) reinforced with GFRP bars through finite element analysis (FEA). A three-dimensional, finite element model of a reinforced HSCB was proposed using non-linear finite elements software. The proposed model considers the impact of cracks in concrete and includes the details of longitudinal as well as transverse reinforcement. The proposed analytical model was verified experimentally through an experimental study conducted for three simply supported beam specimens. The first specimen was reinforced in flexure with steel bars; the second specimen was reinforced with GFRP bars, and the third specimen was reinforced with GFRP bars in addition to steel fibers with volume of $1.0 \%$. A close agreement between the experimental results and the corresponding analytical results was obtained. Then, the verified model was used to study the effect of the change in the compressive strength of concrete and the ratio of longitudinal GFRP bars on the behavior of the reinforced concrete beams. The behavior in GFRP-reinforced concrete beams was different with the change of concrete strength and GFRP ratio when subjected to a given load, where when using a GFRP ratio up to $0.5 \%$ with HSC equal to or more than $60 \mathrm{MPa}$, the rupture of the GFRP bars occurred before crushing in the concrete; Also, it was noted that the replacement of steel reinforcement with GFRP bars accelerates the appearance of the initial cracks and increases the failure load in HSCBs, where the first crack in the beams reinforced with, GFRP bars, GFRP bars and containing $1.0 \%$ of steel fiber, and steel bars were 22.5 $\mathrm{kN}, 29 \mathrm{kN}$, and $42 \mathrm{kN}$ respectively. The vertical stiffness for the HSCBs reinforced with steel bars reached
\end{abstract}


BEHAVIOR OF HIGH STRENGTH CONCRETE BEAMS REINFORCED WITH (GFRP) BARS

about 3.5 times and 2.6 times from the stiffness of the HSCBs reinforced with GFRP bars and the HSCBs containing $1.0 \%$ of steel fiber reinforced with GFRP bars respectively.

KEYWORDS: High Strength, GFRP, FEA, Corrosion, Cracks, Concrete Beam, ANSYS, Steel Fiber.

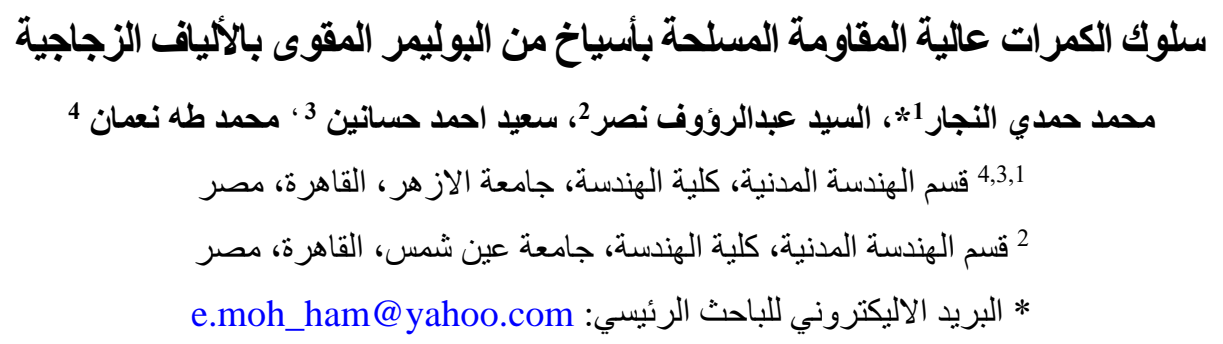

الملخص

يزداد البحث عن بديل لحديد التسليح غير قابل للتآكل يوميًا، خاصة في المنشآت المعرضة لهجمات كيميائية مثل الكربنة في الظروف البيئية

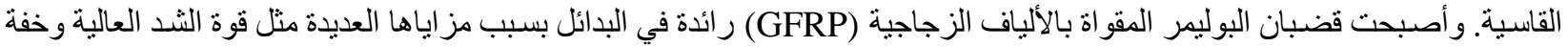

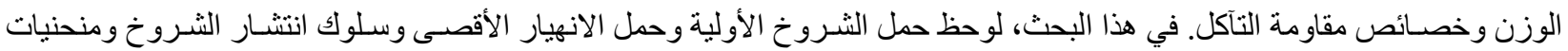

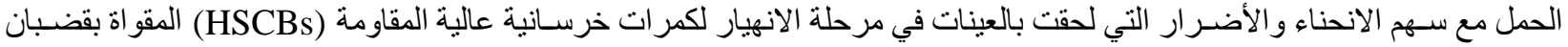

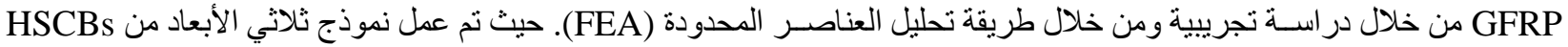

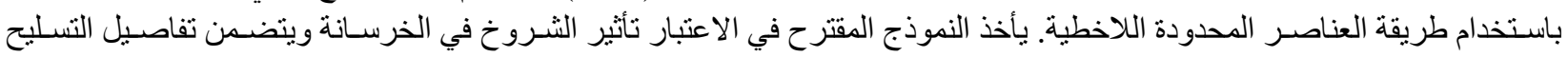

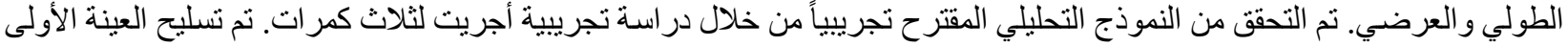

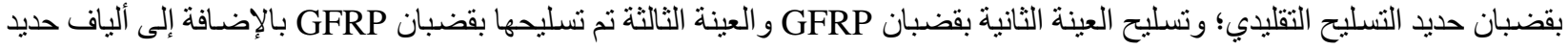

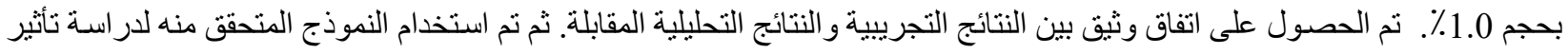
التغير في مقاومة الضغط للخرسـانة ونسبة تسليح GFRP الطولية على سلوك كأك الكمر ات الخرسـانية المسلحة في الانحناء. كان السلوك في في

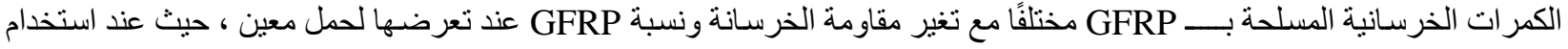

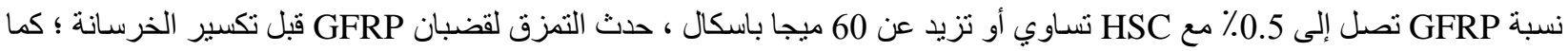

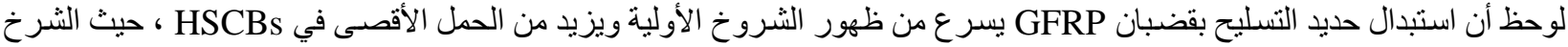

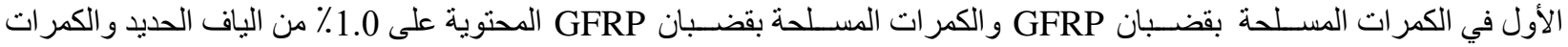

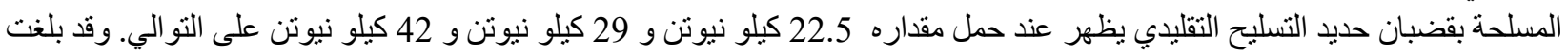

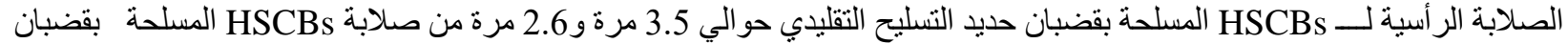
المسلحة بقضبان GFCBs وGFRP المحتوية على 1.0 \% من الألياف على التوالي. الكلمات المفتاحية: مقاومة عالية، البوليمر المقوى بالألياف الزجاجية، العناصر المحدودة، التآكل , شروخ ,ألياف الحديد ,كر ات مسلحة انسيز

\section{INTRODUCTION}

The corrosion of steel reinforcement is a serious problem concern all over the world. The highly corrosive environments such as seawalls create a harsh environment, accelerating the corrosion of the steel reinforcement in these structures. The corrosion and related deterioration necessitate costly repairs and reduce the service life of concrete structures. It might lead to catastrophic failures. Replacing corrodible steel reinforcement with non-corroding GFRP bars provides a suitable solution for eliminating the potential of corrosion and its related deteriorations [1]. In recent years, research have been conducted several studies on glass fiber reinforced plastic (GFRP) bars as an alternative to steel reinforcement. The GFRP bars have already shown a promising future to overcome the corrosion problem in many projects, especially in bridge decks and parking garage [2]. This is because of the GFRP advantages such as high longitudinal strength, corrosion resistance, high fatigue endurance, lightweight, and low thermal and electrical conductivities. In 
order for GFRP bars to become widely accepted in the construction industry, all aspects of their structural behavior must be studied to guarantee their safe application[4]. Several researchers have studied the feasibility of using GFRP bars for the reinforcement of various concrete elements. Szczech and Kotynia found that the GFRP bars indicated good bond behavior to concrete. While the average bond strength was slightly lower than that of steel reinforcement bars with diameters of $16 \mathrm{~mm}$ and $18 \mathrm{~mm}$, the bond was higher for the GFRP bars of $12 \mathrm{~mm}$ diameter[5]. Huang et al, experimentally, investigated the bond properties and stress-slip relations between GFRP bars and hybrid fiber-reinforced concrete (HFRC) containing carbon, Aramid, and polypropylene fibers. The test results indicated that the bond behavior between the GFRP bars and HFRC was significantly improved by the cooperative effects of the carbon, polypropylene, and aramid fiber[6]. Parvizi et al. found that there is no statistically significant difference in the short-term (28 day) bond strength of GFRP bars in seawater concrete compared to normal concrete[7]. El-Nemr et al., investigated the flexural behavior and serviceability performance of concrete beams reinforced with different types of GFRP bars that their surface profile was sand-coated, helical, and grooved. It was noticed that the cracking behavior of the tested beams tends to confirm that sand-coating of GFRP bars enhances the bond performance in concrete more than the helically grooved profile[8]. Basaran and Kalkan developed bond strength and development length formulas for FRP bars in concrete depending on a database of 185 tests compiled. This database included a great majority of the factors affecting the FRP-concrete bond, and then compared proposed formulas to the bond strength and development length equations of the international FRP-reinforced concrete codes. The main results of this study indicated that the proposed bond strength formula is more accurate in estimating the bond strength values of FRP bars compared to the codes equations [9]. Awad-Allah et al., produced glass fiber reinforcing bars able to resist fire and high temperature. Many attempts were conducted locally aimed to produce resins able to resist the high changes in temperature for long durations. It was found that tire carbon (C330-10\%) has high efficiency to resist the high temperatures with longer melting time [10]. Qin et al.[11], aimed to increase the stiffness and flexibility of the concrete beams at the same time. They suggested that the best ratio of FRP area to steel area $\left(\mathrm{A}_{\mathrm{f}} / \mathrm{A}_{\mathrm{s}}\right.$ ) in over-reinforced beam design had a range of 1 to 2.5 to provide enough post-elastic strength and stiffness for meeting the ductility requirement. It was also shown that the use of hybrid FRPRC in under-reinforced beam design is an economical method[11]. Gribniak et al. investigated the effect of the arrangement of GFRP tensile reinforcement on the flexural stiffness and cracking of concrete beams. No relationship was found between crack widths and the crack spacing when the reinforcement layout changed. It was found that the maximum crack opening was not necessarily adjacent to the maximum distance between cracks. The results showed that the number of reinforcement layers increases the flexural stiffness[12]. Krall and Polak presented experimental research on the flexural and shear behavior of concrete beams reinforced with GFRP composite reinforcement. It was observed that the beams without stirrups failed in shear tension while the beams with stirrups failed in shear compression with no ruptured stirrups and it was found diminishing increases in shear strength with increasing shear reinforcement ratio when a failure occurred as a result of crushing of confined concrete[13]. Yang et al. concluded that the energy dissipation in GFRP-reinforced concrete beams were different from those of steel-reinforced concrete beams when subjected to a given load where the average cracking loads of the steel-reinforced concrete beam was 1.61 times as much as that of the GFRP-reinforced concrete beam. It was found after the first crack occurred that all of the force in the beam is transferred to the GFRP bar. So the stress gradually built up in the concrete as a result of the bond stress between the GFRP bar and the concrete far from the crack [14]. El-Mogy et al., investigated the flexural behavior of continuous concrete beams reinforced with FRP and their capability of moment redistribution. His experimental results showed that moment redistribution in FRP-reinforced continuous 
concrete beams is possible if the reinforcement configuration is chosen properly, and is improved by increasing the amount of transverse reinforcement[15]. Elchalakani et al. tested 17 rectangular concrete columns reinforced with steel or GFRP. 13 specimens were tested as columns and 5 specimens were tested as beams. It was noticed that the low elastic modulus of GFRP made it especially susceptible to buckling and that the lateral restraint of longitudinal rebars is thus critical for eccentrically loaded GFRP-reinforced concrete columns, and provided derivations of the interaction diagrams for both steel- and GFRP-reinforced concrete columns [16]. Ashour et al. tested twenty-seven reinforced high strength concrete beams to study the effects of longitudinal tensile reinforcement ratio of steel. Steel fiber content and compressive strength on flexural behavior of reinforced concrete beams. It was noticed that the amount of tensile reinforcement ratio did not affect the additional moment strength that was provided by fibers. Also, when the concrete compressive strength and steel fiber content increased, the flexural rigidity increased significantly[17]. Song and Hwang investigated the mechanical properties of high-strength steel fiber-reinforced concrete. The compressive strength of the fiber-reinforced concrete reached a $1.0 \%$ volume fraction, being an $11.8 \%$ improvement over the HSC[18].

\section{LABORATORY EXPERIMENTS}

\subsection{General}

In order to achieve the aimed goals of the present study, a 3D finite element model was proposed to spread the different parameters and increase the number of specimens. To verify this model, an experimental program was conducted. It consisted of three simply supported beams; a beam reinforced with steel bars; a beam reinforced with GFRP bars and a beam reinforced with GFRP bars added to it the steel fibers at the volume ratio of $1.0 \%$.

\subsection{Test Specimens}

The RC beams with overall dimensions of $125 \mathrm{~mm}$ width, $250 \mathrm{~mm}$ height and $2000 \mathrm{~mm}$ length were tested. The beams were simply supported with a clear span of $1800 \mathrm{~mm}$. The bottom longitudinal reinforcement was: - 3 GFRP bars with diameter of $10 \mathrm{~mm}$ for two beams and 3 high grade steel bars for the other beam. The top reinforcement was 2 high grade steel bars with diameter of $10 \mathrm{~mm}$ for all beams. The steel bars in the top reinforcement of the beams was used in compliance with the recommendations of ECP 2082005[19]. The stirrups were normal mild steel, $8 \mathrm{~mm}$ diameter, at $100 \mathrm{~mm}$ spacing to avoid shear failure of the beams as shown in Table1, Fig. 1and Fig.2.

Table1: Details of beams

\begin{tabular}{cccccc}
\hline No. & Model & $\begin{array}{l}\text { Fiber } \\
\text { Volume } \\
\text { Fraction } \\
(\%)\end{array}$ & $\begin{array}{l}\text { Bot. } \\
\text { Rein. } \\
\text { Type }\end{array}$ & $\begin{array}{l}\text { Bot. } \\
\text { Rein. } \\
(\%)\end{array}$ & $\begin{array}{l}\text { Top } \\
\text { Rein. } \\
\text { (Steel) }\end{array}$ \\
\cline { 1 - 4 } $\mathbf{1}$ & $3 \mathrm{~S} 10$ & 0 & Steel & & \\
\cline { 1 - 4 } $\mathbf{2}$ & $3 \mathrm{G} 10$ & 0 & GFRP & $0.75 \%$ & $2 \varnothing 10$ \\
\cline { 1 - 4 } $\mathbf{3}$ & 3 G11 & 1.0 & GFRP & & \\
\hline
\end{tabular}




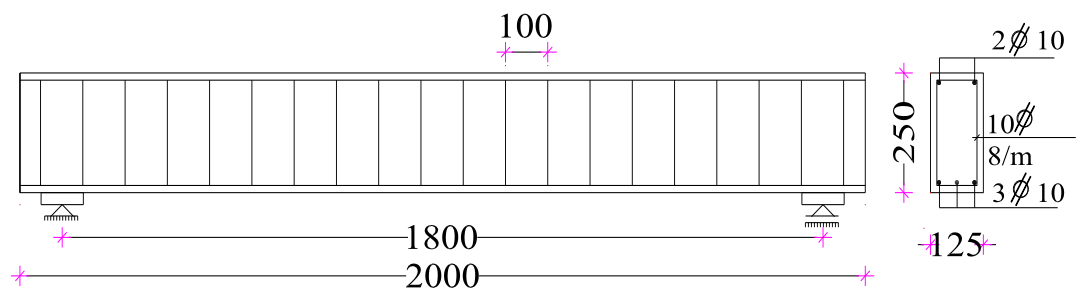

Fig. 1: Dimensions and reinforcement details

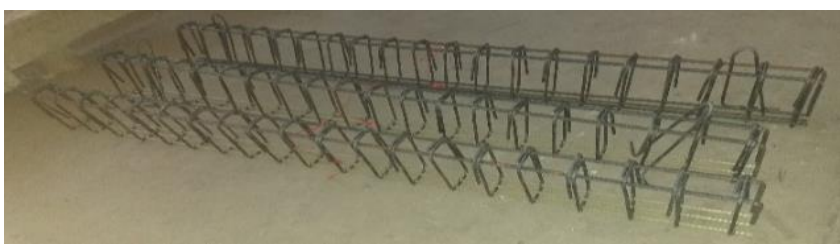

Fig.2: Reinforcement for beams

\subsection{Fabrication of Test Specimens}

The specimens were fabricated at the Concrete Laboratory of the Civil engineering Department, Faculty of Engineering, Al-Azhar University. The reinforced concrete specimens were fabricated where reinforcement cages were prepared, then the formwork was made of thick ply-wood, and then GFRP bars reinforcement was installed in the formwork. Then, concrete was cast with a target cube compressive strength of $60 \mathrm{MPa}$. The concrete was compacted after casting using an electrical vibrator for three minutes. The curing of specimens with water was started 24 hours after casting for 14 days, as shown in Fig. 3.

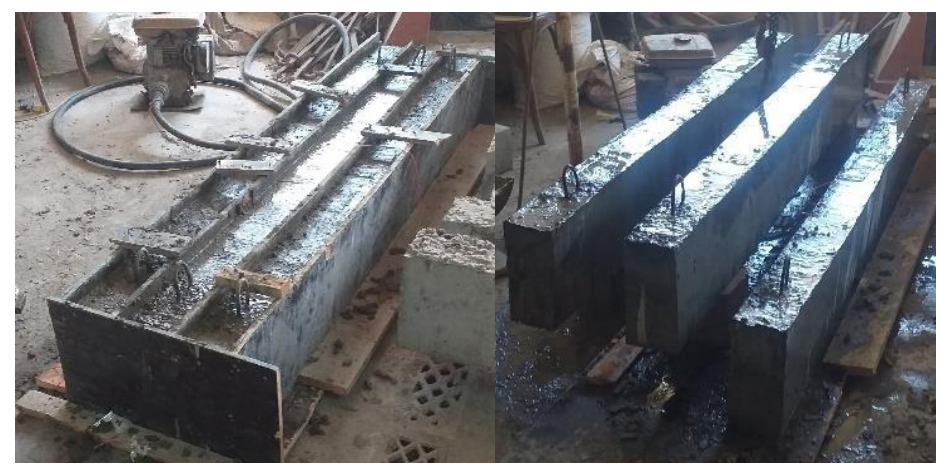

Fig. 3: Casting and curing

\subsection{Material Properties}

The test specimens used in this program were made from local material except GRFP bars. The coarse aggregates were composed of dolomite of good quality with a maximum size of $1 \mathrm{~cm}$. The batches used were all of good quality with uniform characteristics and free from injurious materials. The partial shape was generally a combination of round and sub-angular. Moreover, Fine aggregate used was composed of the sand siliceous material. It was clean and free from injurious and organic materials. Torah Portland cement CEMI $52.5 \mathrm{~N}$ was used in the experimental work, which conforms to the Egyptian standard specification (ES 4756/1-2007) for Portland cement. The water used in all mixes was clean drinking fresh water free from impurities. The value of water / cement ratio used was chosen based on the total weight of water added to 
air dry materials where it was $37.5 \%$. No allowance had been made for the absorption of mixing water by the aggregates. Two different types of steel were used in this study; one of them was normal mild steel with yield strength $240 \mathrm{MPa}$, and the other was high tensile steel with yield strength 400MPa. The normal mild steel bars were round, smooth and with diameter of $8 \mathrm{~mm}$ that were used as stirrups. The high tensile steel bars were round, not smooth, and with diameters of 10 and were used for the top reinforcement. The mechanical characteristics of high tensile steel, as reported by manufacturer are presented in Table 2.The GFRP bars used in the experimental study were straight shaped. Such bars were manufactured by Armastek in Russia and tested in the National Research Centre of Egypt for fiber reinforcement industries company, as shown in . Tensile tests were carried out on three specimens of the bars. The results of ultimate strength, strain, and elastic modulus are listed in

Table 3: Mechanical characteristics of GFRP bars

\begin{tabular}{cccc}
\hline Properties of GFRP bars & \multicolumn{3}{c}{ Sample No. } \\
\cline { 2 - 4 } & 1 & 2 & 3 \\
\hline Nominal Diameter $(\mathrm{mm})$ & \multicolumn{3}{c}{10} \\
\hline Nominal Area $(\mathrm{mm} 2)$ & \multicolumn{3}{c}{138.57} \\
\hline Mass per Meter Run $(\mathrm{gm} / \mathrm{mm})$ & 85.5 & 77.84 & 80.72 \\
\hline Ultimate Load $(\mathrm{KN})$ & 1088 & 990.71 & 1027.3 \\
\hline Ultimate Tensile strength $(\mathrm{MPa})$ & N.M & 0.0229 & 0.0258 \\
\hline Max. Strain & N.M & 43262 & 39820 \\
\hline Modulus of Elasticity, EG $(\mathrm{MPa})$ & & &
\end{tabular}

. The steel fiber used in this study was hooked end type with an aspect ratio of (L/D) 43.75 as shown in Fig.4: GFRP bars

Fig. 5 . The basic dimensions of this fiber were $35 \times 0.8 \mathrm{~mm}$ with $45^{\circ}$ hooked ends which are generally considered too slow to deform during pull-out from concrete ensuring a controlled ductile failure. However, it must be noted that adding a large amount of relatively long and stiff steel fibers into concrete may cause workability problems. The fiber content of $78.5 \mathrm{~kg} / \mathrm{m} 3$ adopted is corresponded to $1.0 \%$ by volume of the concrete matrix for the specimen (3G11).

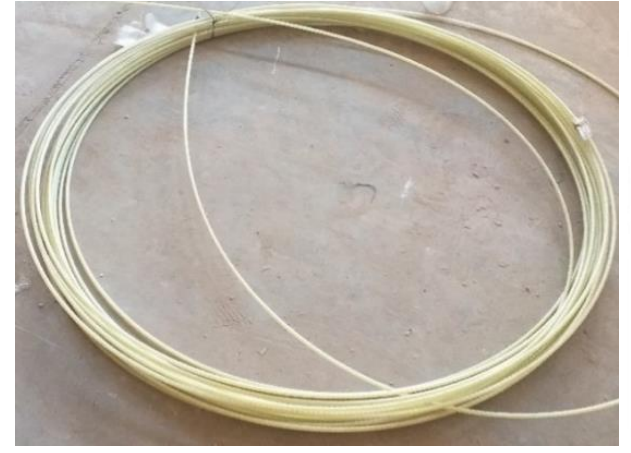

Fig.4: GFRP bars

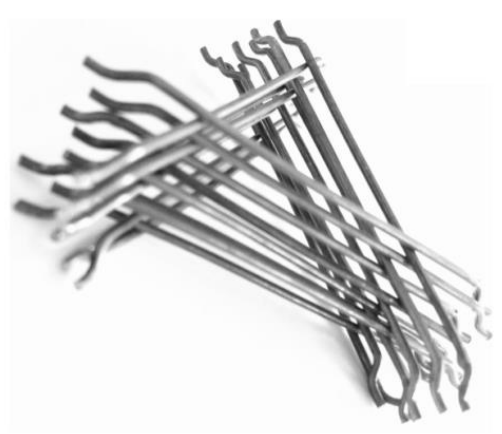

Fig. 5: Hooked steel fiber

Table 2. Mechanical characteristics of high tensile steel

\begin{tabular}{cc}
\hline Steel Properties \\
\hline yield strength " $f y$ ” $(\mathrm{MPa})$ & 400 \\
\hline
\end{tabular}




\begin{tabular}{cc}
\hline Ultimate Strength "fu” $(\mathrm{MPa})$ & 520 \\
\hline Young's Modulus "E" $(\mathrm{MPa})$ & 200,000 \\
\hline Yield Strain "Ey" & 0.002 \\
\hline Strain at Maximum load "cy” & 0.008 \\
\hline Maximum Strain "cy" & 0.016 \\
\hline
\end{tabular}

Table 3: Mechanical characteristics of GFRP bars

\begin{tabular}{cccc}
\hline Properties of GFRP bars & \multicolumn{3}{c}{ Sample No. } \\
\cline { 2 - 4 } & 1 & 2 & 3 \\
\hline Nominal Diameter $(\mathrm{mm})$ & \multicolumn{3}{c}{78.57} \\
\hline Nominal Area $(\mathrm{mm} 2)$ & \multicolumn{3}{c}{138} \\
\hline Mass per Meter Run $(\mathrm{gm} / \mathrm{mm})$ & 85.5 & 77.84 & 80.72 \\
\hline Ultimate Load $(\mathrm{KN})$ & 1088 & 990.71 & 1027.3 \\
\hline Ultimate Tensile strength $(\mathrm{MPa})$ & N.M & 0.0229 & 0.0258 \\
\hline Max. Strain & N.M & 43262 & 39820 \\
\hline Modulus of Elasticity, EG $(\mathrm{MPa})$ & & &
\end{tabular}

\subsection{Concrete Mix}

A study was carried out to obtain a concrete mix to achieve the proposed compressive strength (60MPa). Mix proportioning of concrete are presented in Table 4.

Table 4: Proportioning of concrete mix

\begin{tabular}{cc}
\hline Compound & Amount to $1 \mathrm{~m} 3$ \\
\hline CEMI52.5N $(\mathrm{kg})$ & 500 \\
\hline Dolomite $(\mathrm{kg})$ & 970 \\
\hline Sand $(\mathrm{kg})$ & 780 \\
\hline Water $(\mathrm{kg})$ & 185 \\
\hline Silica Fume $(\mathrm{kg})$ & 25 \\
\hline Superplasticizer $(\mathrm{kg})$ & 12.50 \\
\hline
\end{tabular}

\subsection{Specimens Preparation and Test Set-Up}

Three standard cubes, 150x150x150 mm, were taken from the concrete mix during the casting of each specimen. Results of the cubes tests after 28 days are presented in Table 5. Instrumentation of specimens included three Linear Variable Displacement Transducers (LVDT) were used for measuring deflection at three points, strain gauges were used for GFRP Bars at the mid-bar, strain gauges were used for concrete at top mid-span, and a load cell to measure the load of the testing machine as shown Fig. 6: Instrumentation used. The tests were carried out under a controlled load of four-point loading up to failure using a manual hydraulic jack of $1000 \mathrm{KN}$ capacity as shown in

Fig. 7. The load increment was constant for beams specimens at $5 \mathrm{kN}$. Two concentrated loads at $300 \mathrm{~mm}$ from the mid span were applied on the beam using a distributing steel I-beam, supported on two steel rods and rested on neoprene pads. During testing, the loading was paused at different load levels to visually inspect the beam. Crack propagation was visually observed and the cracks were marked on the surface of the tested specimen. 
Table 5: Compression test results on standard cubes

\begin{tabular}{cccc}
\hline Cube & 3S10 & 3G10 & 3G11 \\
\hline $\mathbf{F}_{\text {cu }}(\mathbf{M P a})$ & 58.7 & 58.7 & 64.5 \\
\hline
\end{tabular}

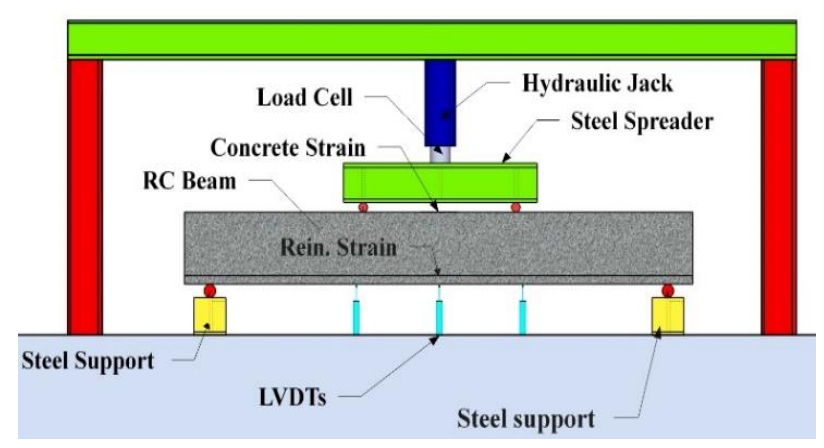

Fig. 6: Instrumentation used

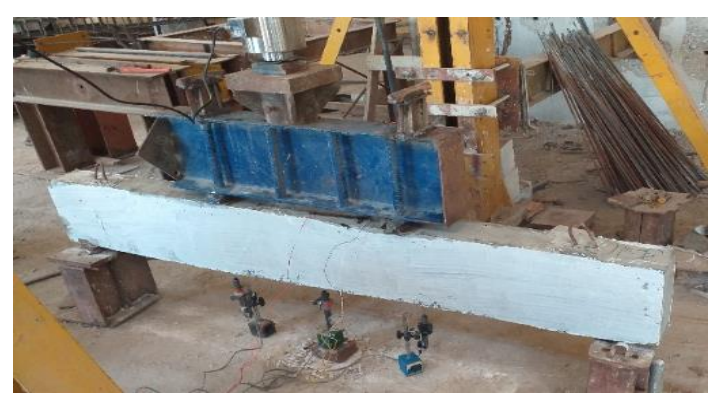

Fig. 7: Test set up and load pattern

\subsection{Results of Experimental Study}

The failure loads and vertical deflections for all specimens were summarized in Table 6. It is noted that replacing the steel with GFRP bars increases the failure load by about $31.1 \%$. Replacing the steel with GFRP bars in addition to $1 \%$ of the steel fibers increases the failure load by about $50.1 \%$. The steel-reinforced concrete beam failed due to yielding in steel bars followed by concrete crushing in compression zone (ductile failure). On the contrary, the GFRP reinforced concrete beam failed due to crushing in concrete followed by GFRP bars rupture_(brittle failure). Fig. 8 shows the relationship between the load and the vertical deflection at mid-span for specimens. the typical load-deflection behavior of 3S10 beam was linear up to crack load. But after cracking, the relationship was less sloped. when the yield of the longitudinal steel reinforcement was reached; the behavior changed to be nonlinear up to failure. In contrary, the GFRP reinforced concrete beams were linear up to failure. But after cracking, the linear slope decreased.

Table 6: Failure loads, deflection, steel strain, concrete strain at failure and observed modes of failure for beams

\begin{tabular}{cccccc}
\hline $\begin{array}{c}\text { Specimen } \\
\text { no }\end{array}$ & $\begin{array}{c}\mathrm{P}_{\mathrm{u}} \\
(\mathrm{KN})\end{array}$ & $\begin{array}{c}\Delta_{\mathrm{u}} \\
(\mathrm{mm})\end{array}$ & $\begin{array}{c}\varepsilon_{\mathrm{cmax}} \\
(\%)\end{array}$ & $\begin{array}{c}\varepsilon_{\mathrm{rmax}} \\
(\%)\end{array}$ & Failure modes \\
\hline $3 \mathrm{~S} 10$ & 99.5 & 19.4 & $0.0144 \%$ & $0.27 \%$ & Ductile \\
\hline $3 \mathrm{G} 10$ & 130.5 & 35.28 & $0.173 \%$ & $1.95 \%$ & Brittle \\
\hline $3 \mathrm{G} 11$ & 149.4 & 27.46 & $0.299 \%$ & $1.27 \%$ & Brittle \\
\hline
\end{tabular}




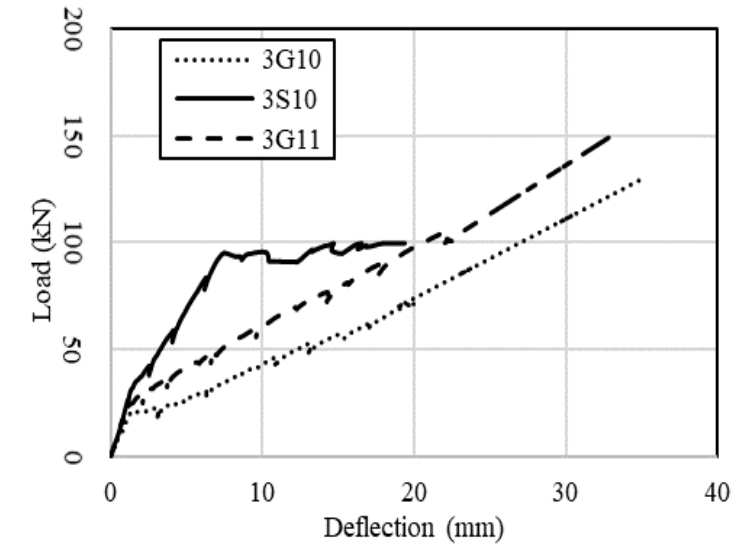

Fig. 8: Load -Deflection at mid-span relationship

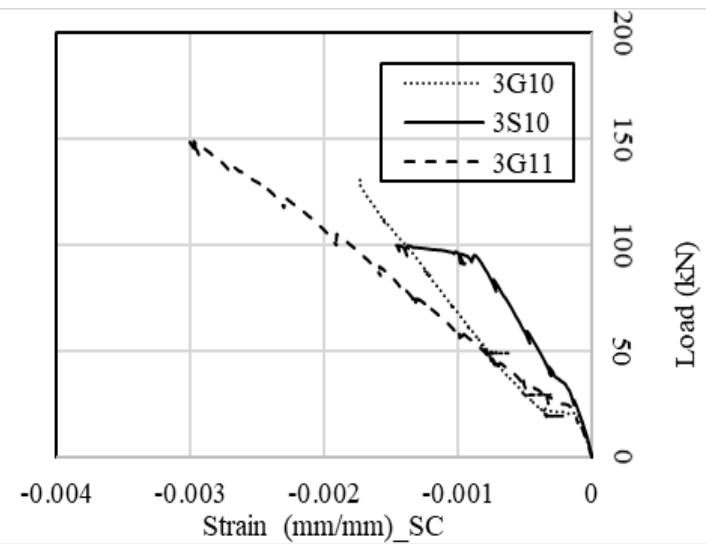

Fig. 9: Load-Compressive concrete strain at mid-span

Fig. 10 shows the load - tensile strain relationship in the flexural bottom bars at the mid-span. It could be noted for 3S10 beam, that the tension steel bars started to yield near the failure load. For beams with GFRP bars, it was noticed that the tension GFRP bars strained linearly up to first concrete cracking. started with a linear followed by a horizontal line when the concrete cracked, then it is returned linearly again, but with a less slopy due to it is exposure to a large part of the stresses.

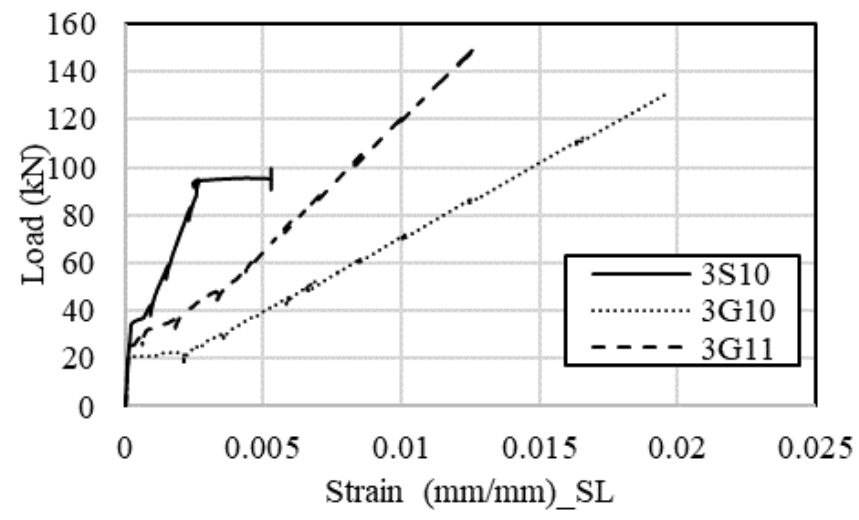

Fig. 10: Load-longitudinal tensile strain relationship for bottom reinforcement

Fig.11shows the relationship between the vertical stiffness and the vertical load at mid-span for specimens. Where vertical stiffness is the extent of the beam's resistance to deflection due to the loads applied to it. As the vertical load increased, the stiffness started to decrease for all beams. However, the rate of decrease in the stiffness of 3S10 beam was less than the other beams due to the high modulus of elasticity of steel versus GFRP bars, which reach 5 times of it. Where, at a given load such as $40 \mathrm{kN}$, its stiffness was higher than 3G10 and 3G11 by $150 \%$ and $97.9 \%$, respectively. Where the presence of steel fiber in the beams reinforced with GFRP bars as an admixture to concrete (3G11) resulted in a lower rate of deterioration of the stiffness than that the stiffness of the $3 \mathrm{G} 10$ beam which its behavior approached the behavior of beam reinforced with steel beam (3S10). The vertical stiffness for the $3 \mathrm{G} 10$ beam and the $3 \mathrm{G} 11$ beam reached about $30 \%$ and $37.7 \%$ of the stiffness for the $3 \mathrm{~S} 10$ beam as the beams approached failure. 


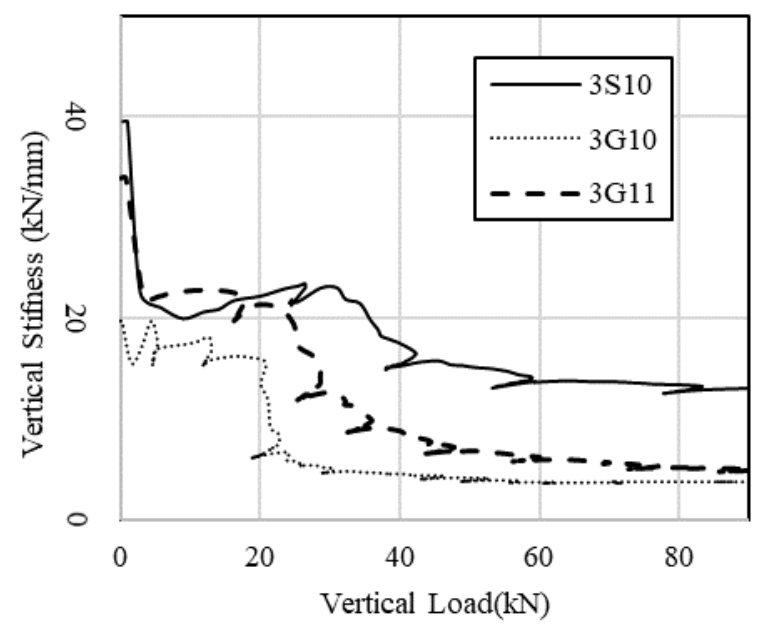

Fig.11: Vertical stiffness for beams
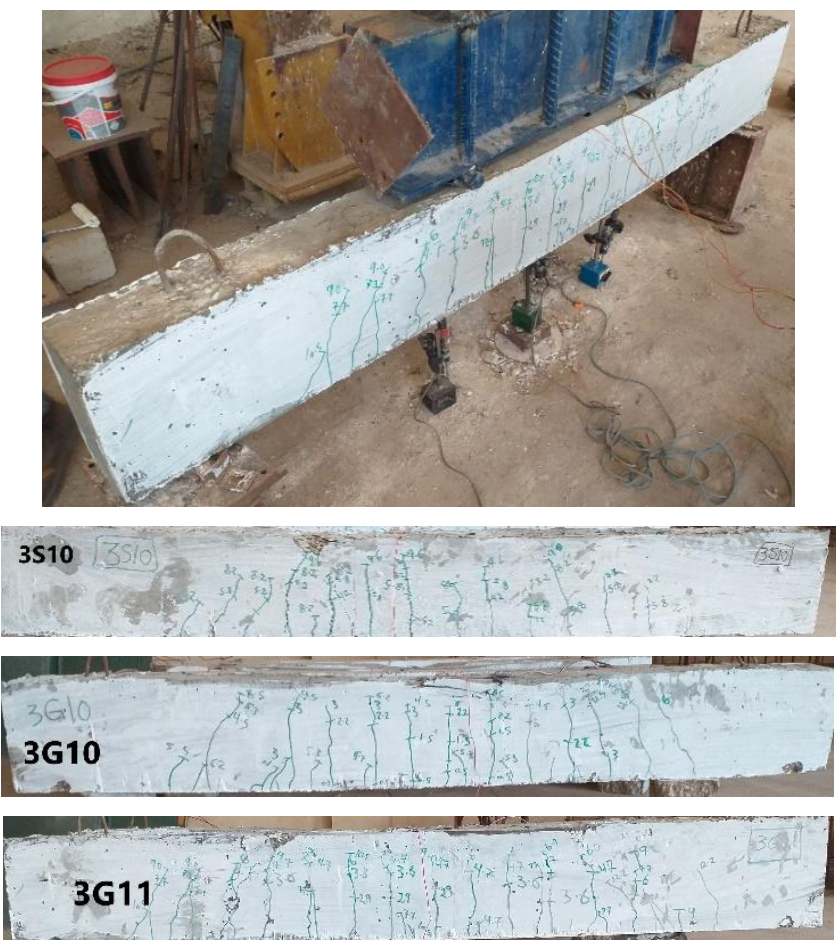

Fig. 12: Crack Pattern of beams at failure

\section{THE FINITE ELEMENT MODEL}

A 3D finite element model for a simple beam (hinged-roller) was constructed using ANSYS [20] finite element package. The details of the model were taken from experimental work performed (3G10). The beam was loaded by two-point loads at 300mm from the mid span as shown in Fig. 13. A SOLID65 3D solid elements was used to represent concrete and LINK180 line truss elements to represent steel and GFRP reinforcement as shown in Fig. 14. The concrete, steel and GFRP stress-strain non-linear curves are shown in Fig. 15. The smeared crack approach was used to represent cracking in concrete. Elements with strong material properties were introduced at the concentrated loads and supports to distribute loads on a large area and prevent premature numerical failures. 


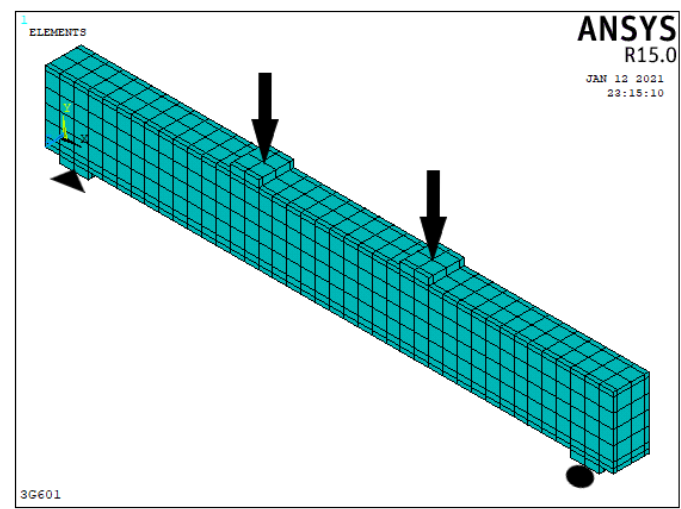

Fig. 13: Location of vertical load
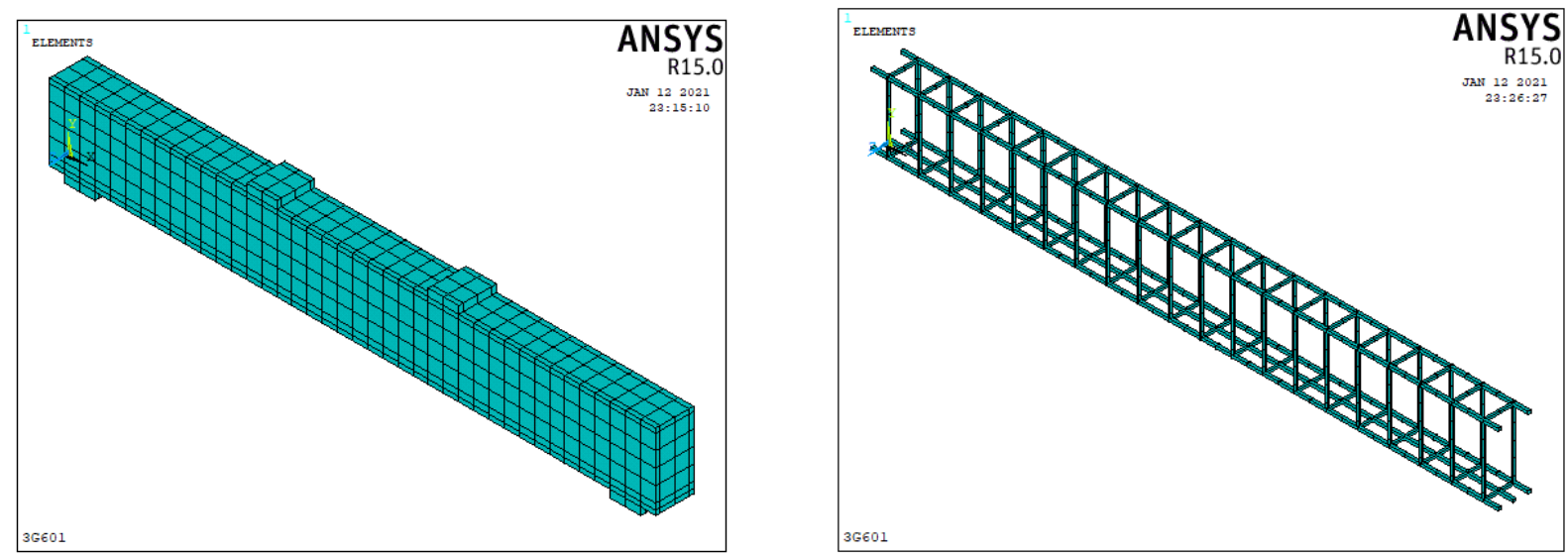

Fig. 14: 3D Finite element model
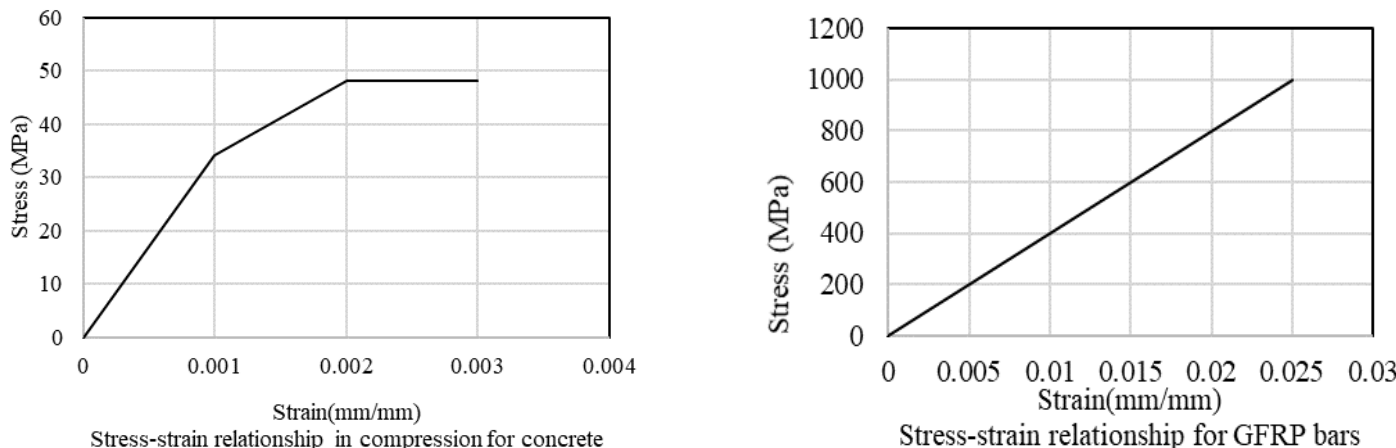

Stress-strain relationship in compression for concrete

Stress-strain relationship for GFRP bars

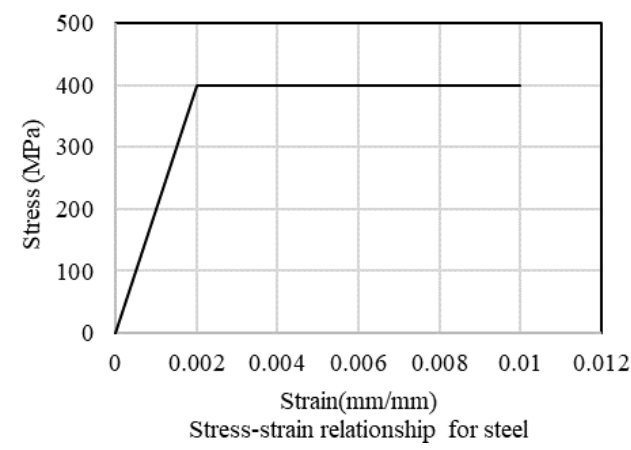

Fig. 15: Concrete, Steel and GFRP Bars Reinforcement stress-strain curves 


\section{EXPERIMENTAL VERIFICATION}

The confidence in the results of the finite element model was verified using the experimental work (3G10). The results obtained by the 3D finite element model were close to the experimental results.

\subsection{Failure Load and Deflection}

Fig. 16 shows the load - mid-span deflection relationship for the experimental specimen and the finite element model. The failure load of the specimen was $148 \mathrm{KN}$ as cored to $130.5 \mathrm{KN}$ in the experimental study. The maximum deflection was $36 \mathrm{~mm}$ cored to 38 in the experimental study. The load deflection relation showed similar behavior.

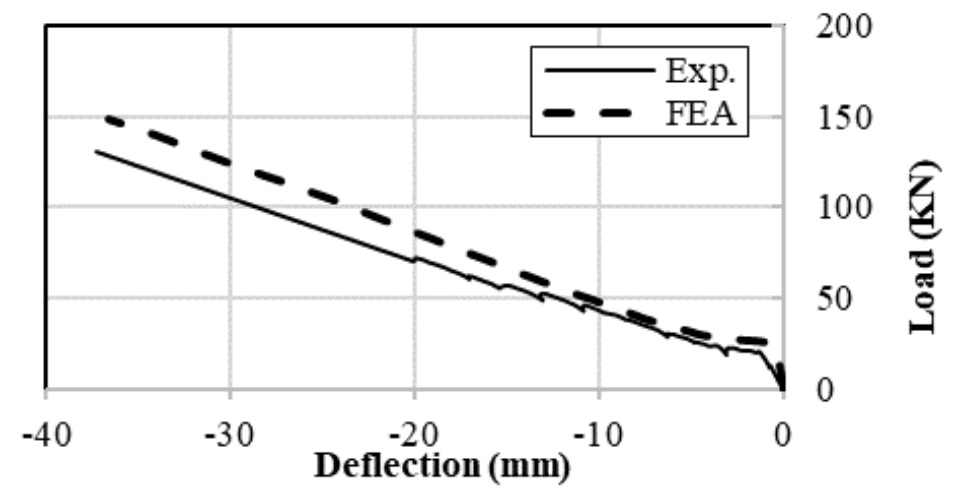

Fig. 16: Load -deflection at mid-span relationship in Exp. \& FEA

\subsection{Concrete and Reinforcement Strain}

Fig. 17 shows the relation between the load and the concrete strain at top of the beam measured at mid-span for both the experimental and finite element models. Similar behavior for both cases was noticed.

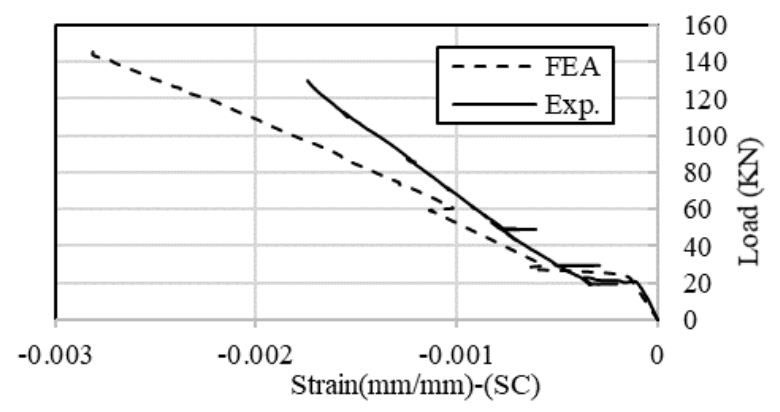

Fig. 17: Load -compressive concrete strain at mid-span section

Fig. 18 shows the relation between the load and bottom longitudinal steel strains at mid-span for the experimental and finite element models. The experimental results and finite element results showed the same behavior and the values were very near. 


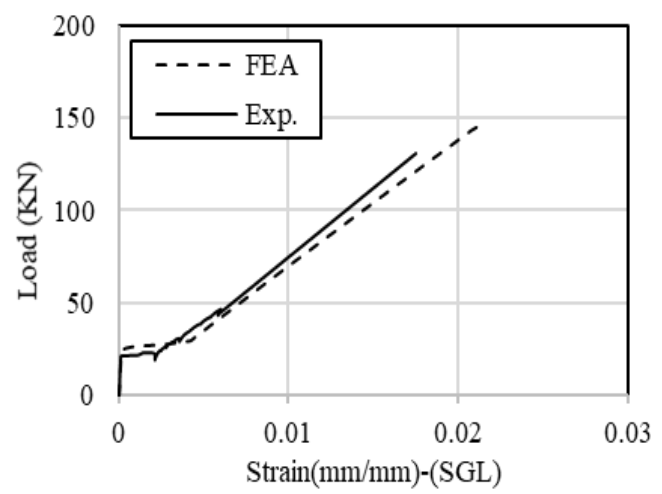

Fig. 18: Load-longitudinal tensile strain relationship for bottom GFRP reinforcement in EXP \&FEA

\subsection{Cracking at Failure}

Fig.19 shows a comparison of the cracking in both the finite element and the experimental model near the failure load. As shown in the figure, cracking was similar for both models. The comparison between the finite element results and the experimental results showed similar behavior.
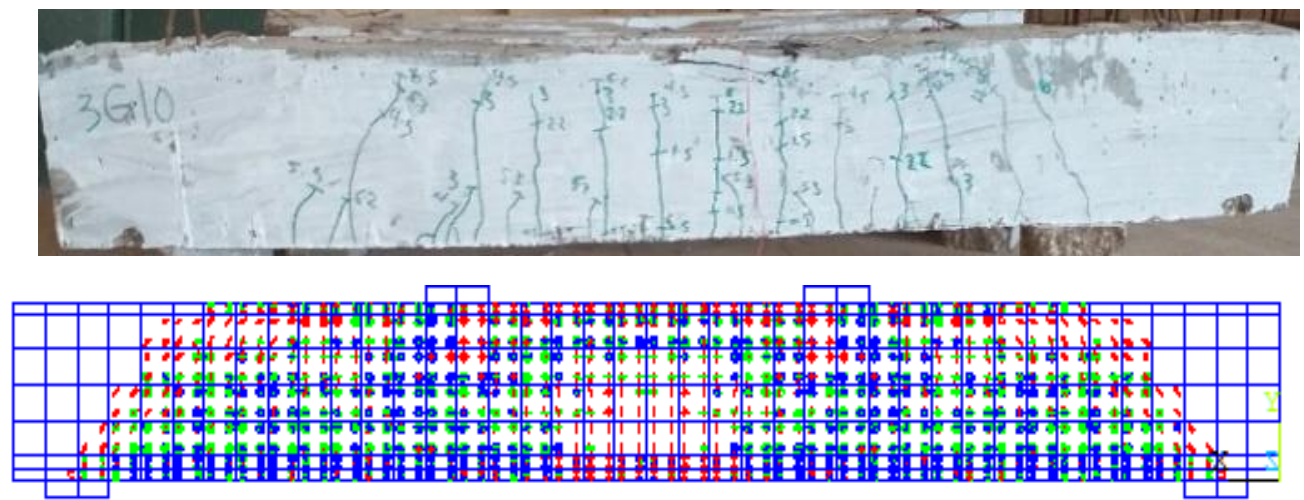

Fig.19: Crack Pattern of beam at failure EXP. vs. FEM

\section{PARAMETRIC STUDY}

To study the effect of flexural tensile GRFP bars ratio on the flexural behavior of reinforced HSCBs, a nonlinear finite element model of total of 25 concrete beams were analyzed in the current parametric study. The study was performed on simple beam similar to the pre-examined beam specimens in dimensions, loading pattern and material properties. The studied beams were divided into 5 groups with changing the GRFP bars ratio and the concrete strength. The Concrete compressive strengths of $60,70,80,90$, and 100 and the reinforcement ratios of $0.50,0.75,1.01,1.26$ and $1.51 \%$ were studied as detailed in Table 7 . For all cases, the failure loads, deflection, and strains were cored to study the non-linear effect of GFRP bars ratio on the beam. 
BEHAVIOR OF HIGH STRENGTH CONCRETE BEAMS REINFORCED WITH (GFRP) BARS

Table 7: Studied parameters

\begin{tabular}{|c|c|c|c|}
\hline Group & Model & $\mathrm{F}_{\mathrm{CU}}(\mathrm{MPa})$ & (\%) Bottom Reinf. \\
\hline \multirow[t]{5}{*}{ G60 } & $2 \mathrm{G} 60$ & \multirow[t]{5}{*}{60} & $0.50 \%$ \\
\hline & $3 \mathrm{G} 60$ & & $0.75 \%$ \\
\hline & $4 \mathrm{C} 60$ & & $1.01 \%$ \\
\hline & $5 \mathrm{G} 60$ & & $1.26 \%$ \\
\hline & 6G60 & & $1.51 \%$ \\
\hline \multirow[t]{5}{*}{ G70 } & $2 \mathrm{G} 70$ & \multirow[t]{5}{*}{70} & $0.50 \%$ \\
\hline & $3 \mathrm{G} 70$ & & $0.75 \%$ \\
\hline & $4 \mathrm{C} 70$ & & $1.01 \%$ \\
\hline & $5 \mathrm{G} 70$ & & $1.26 \%$ \\
\hline & $6 \mathrm{G} 70$ & & $1.51 \%$ \\
\hline \multirow[t]{5}{*}{ G80 } & $2 \mathrm{G} 80$ & \multirow[t]{5}{*}{80} & $0.50 \%$ \\
\hline & $3 \mathrm{G} 80$ & & $0.75 \%$ \\
\hline & $4 \mathrm{C} 80$ & & $1.01 \%$ \\
\hline & $5 \mathrm{G} 80$ & & $1.26 \%$ \\
\hline & $6 \mathrm{G} 80$ & & $1.51 \%$ \\
\hline \multirow[t]{5}{*}{ G90 } & 2G90 & \multirow[t]{5}{*}{90} & $0.50 \%$ \\
\hline & $3 \mathrm{G} 90$ & & $0.75 \%$ \\
\hline & $4 \mathrm{C} 90$ & & $1.01 \%$ \\
\hline & $5 \mathrm{G} 90$ & & $1.26 \%$ \\
\hline & $6 \mathrm{G} 90$ & & $1.51 \%$ \\
\hline \multirow[t]{5}{*}{ G100 } & $2 \mathrm{G} 100$ & \multirow[t]{5}{*}{100} & $0.50 \%$ \\
\hline & $3 \mathrm{G} 100$ & & $0.75 \%$ \\
\hline & $4 \mathrm{C} 100$ & & $1.01 \%$ \\
\hline & $5 \mathrm{G} 100$ & & $1.26 \%$ \\
\hline & $6 \mathrm{G} 100$ & & $1.51 \%$ \\
\hline
\end{tabular}




\section{Failure Load}

The failure loads for the proposed GFRP bar ratios obtained from the analysis for different values of the concrete strength are presented in Fig. 20. The figure shows that for each GFRP bar ratio, the increase in the concrete strength increases the maximum load carrying capacity of the specimens significantly. For GFRP bar ratio of $0.5 \%$, non-pronounced increase in the load carrying capacity when increasing the concrete strength was obtained. Whereas, by coring the maximum load with the highest and lowest concrete strength with the same GFRP bar ratio, the maximum load in the lowest and highest GFRP bar ratio increases by $0.03 \%$ and $0.30 \%$ respectively. On the other hand,

Fig. 21, illustrates that the relationship between the maximum load and the concrete strength for different ratios of the GFRP bars. It is noticed that for each value of the concrete strength, the increase in the reinforcement ratio, significantly increases the maximum load carrying capacity of the specimens. For each value of the concrete strength, the most significant increases in the load carrying capacity was noticed for GFRP ratios higher than $0.5 \%$. In all the beams with different concrete strength, and a GFRP ratio of $0.5 \%$, the failure load is almost the same. With the increase in the GFRP ratio from $0.5 \%$ to $0.75 \%$, the failure load dramatically increases to reach $45 \%$ due to the transition from GFRP rupture to crushing in the concrete. When increasing the GFRP ratio from $0.75 \%$ to $1.01 \%$, the failure load increases with small values ranging from $5 \%$ to $15 \%$.

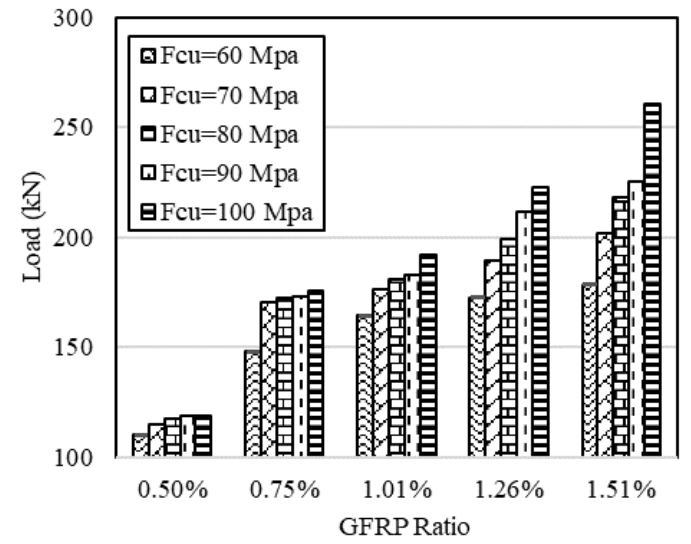

Fig. 20: Load for Varying GFRP ratios

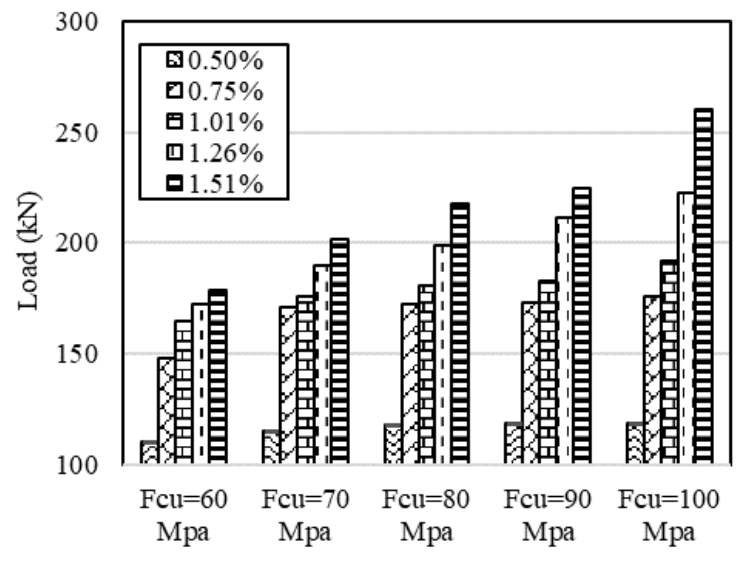

Fig. 21: Load for Varying Compressive Strength

\subsection{Mid Span-Deflection and Reinforcement Strains}

Fig. 24 shows the mid-span deflection for all beams with different concrete strength ranging from 60 up to $100 \mathrm{MPa}$. For all beams, the relation between the load and deflection is initially linear up to the first crack loads followed by a nearly horizontal branch probably due to extensive cracking, then it is followed by a stiffening branch with a considerable increase in load but with a lower stiffness than the initial linear part. Then the failure load occurs suddenly because of the brittle failure of GFRP bars as indicated later in Fig. 25. Increasing the GFRP bars ratio in the studied concrete beams increases the stiffness of the beam after the stage of the first cracks. It was noticed in case of GFRP ratio $0.5 \%$, for all concrete strength values, the GFRP bars failed first followed by concrete crushing (ductile failure). On the other hand, when the GFRP ratio exceeds $0.5 \%$, concrete crushing occurs before failure in GFRP (brittle failure).

\subsection{Cracking}

Flexural cracks began to appear in the middle of the span, and then propagate and expand gradually throughout the beam with increasing loading until the failure as shown in Fig. 22. It is noticed from Fig. 23 that the first crack in all beams having the same strength was not affected by the increase in the GFRP ratio, 
since the first crack appeared at the same load of $22.5 \mathrm{kN}$. On the contrary, with the increase in the strength and the stability of the GFRP ratio, the appearance of cracks is delayed though for a little while, as the cracking load of concrete strength equal to 60 was $22.5 \mathrm{kN}$ and of 100 was $28 \mathrm{kN}$.
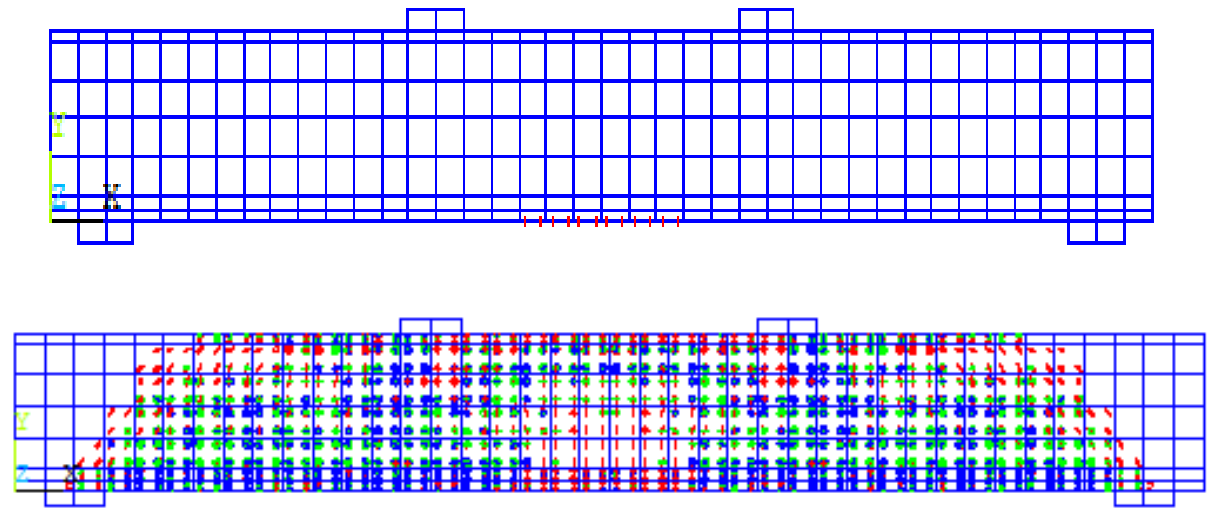

Fig. 22: First \& Failure Crack Pattern of Beams

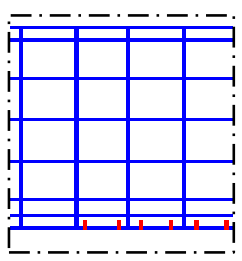

(a)

$\mathrm{F}_{\mathrm{cu}}=60 \mathrm{MPa}$

@ $0.5 \%$ GFRP

F.C. $=22.5 \mathrm{kN}$

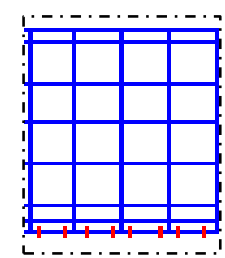

(d)

$\mathrm{F}_{\mathrm{cu}}=100 \mathrm{MPa}$

@ $1.26 \%$ GFRP

F.C. $=28 \mathrm{kN}$

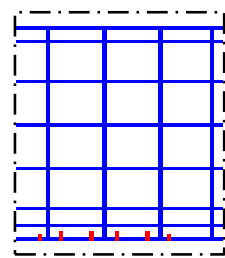

(c)

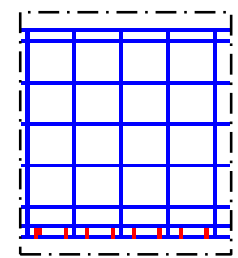

(b)

$$
\begin{array}{cc}
\mathrm{F}_{\mathrm{cu}}=60 \mathrm{MPa} & \mathrm{F}_{\mathrm{cu}}=100 \mathrm{MPa} \\
@ 1.26 \% \mathrm{GFRP} & @ 0.5 \% \mathrm{GFRP} \\
\text { F.C. }=22.5 \mathrm{kN} & \text { F.C. }=28 \mathrm{kN}
\end{array}
$$

Fig. 23: First cracking Load for varying $F_{\text {cu }}$ and GFRP \%

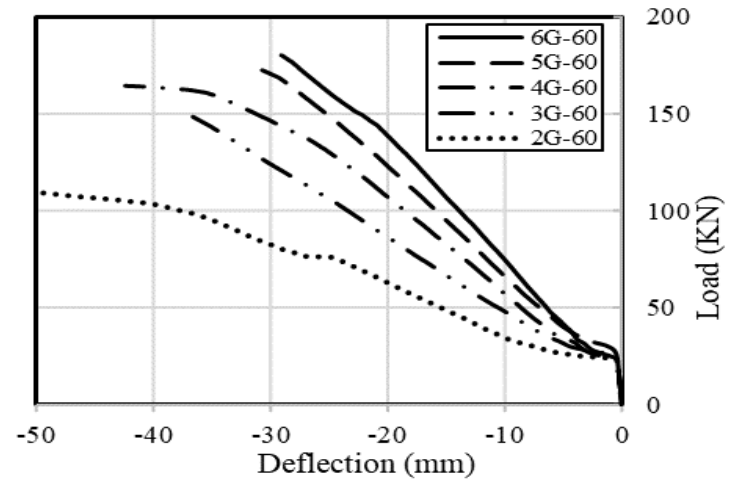

Group (G60)

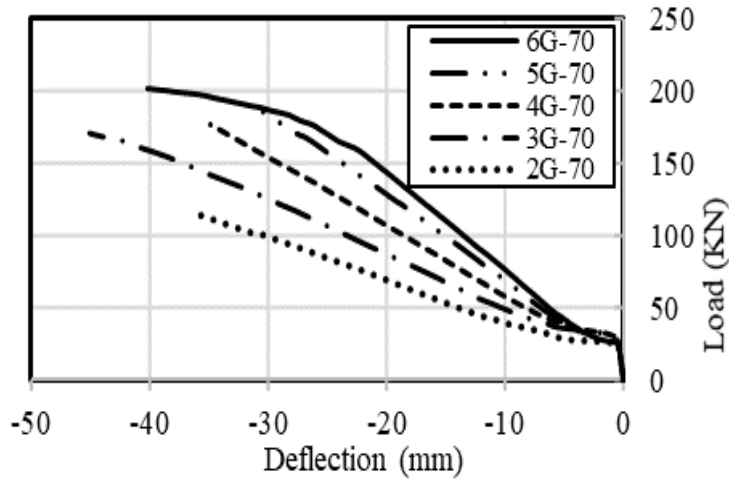

Group (G70) 


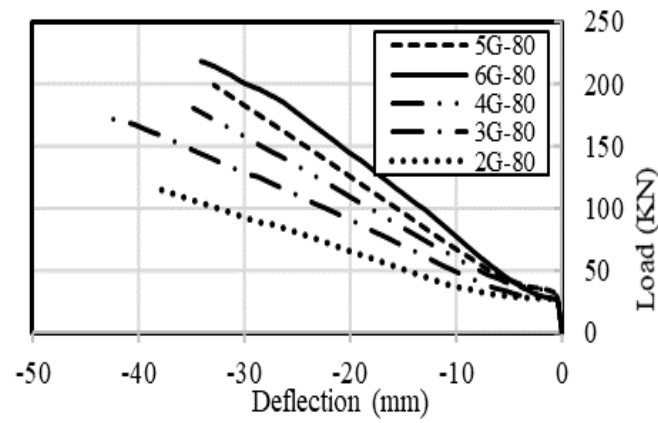

Group (G80)

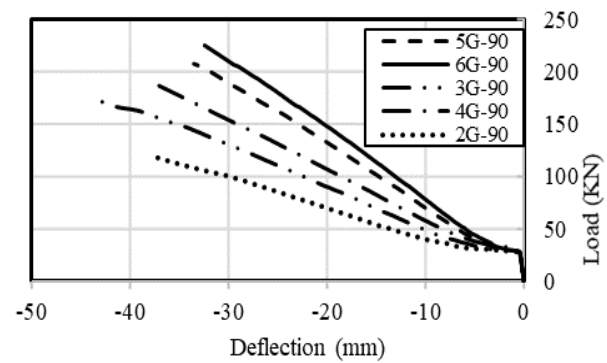

Group (G90)

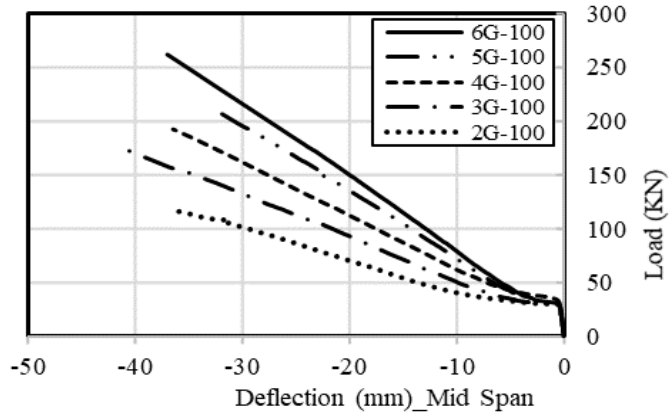

Group (G100)

Fig. 24: Load-deflection curves of beams with GFRP reinforcement

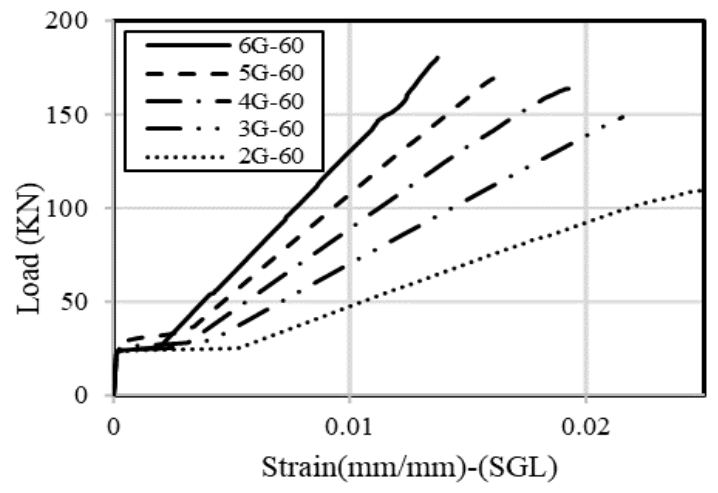

(a) Group (G60)

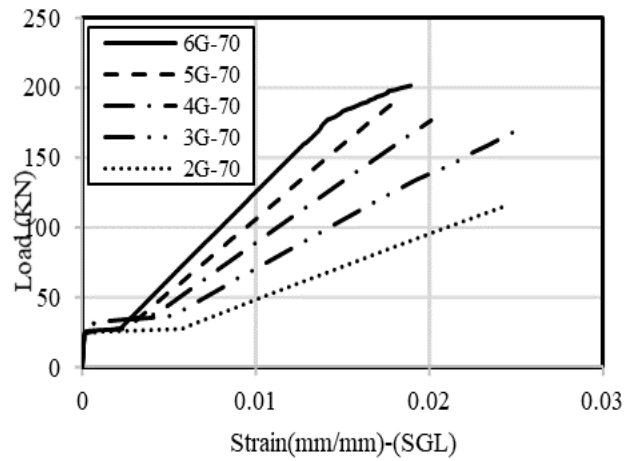

(b) Group (G70)

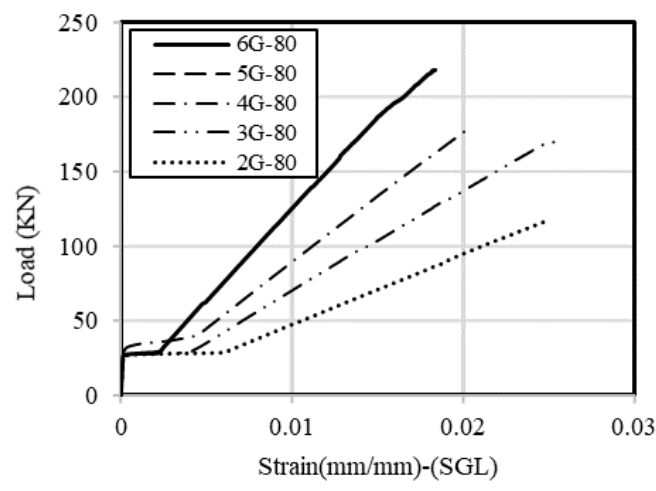

(c) Group (G80)

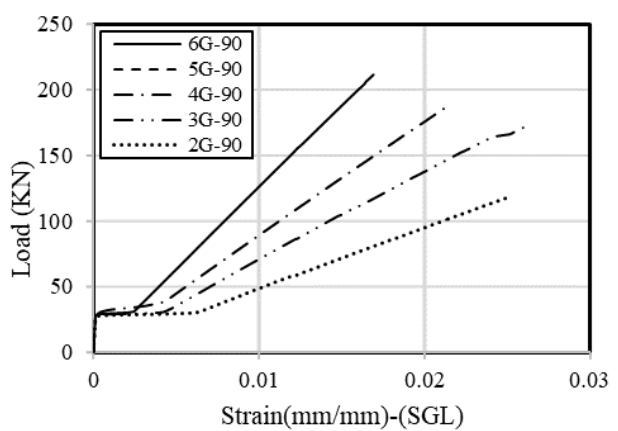

(d) Group (G90) 


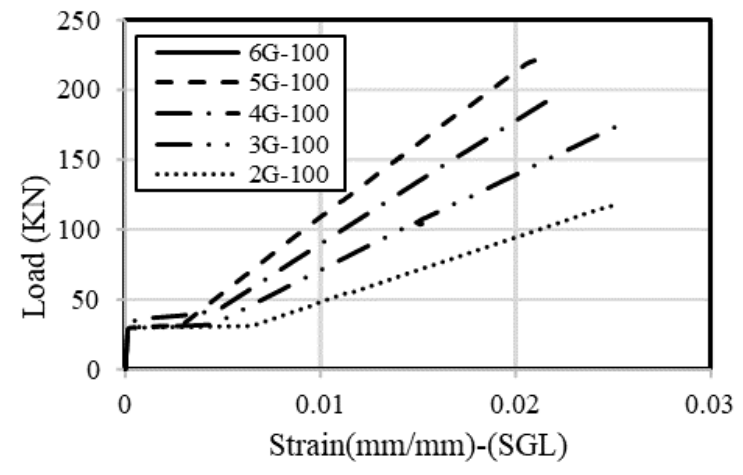

(e) Group (G100)

Fig. 25: Bottom reinforcement strain for different groups

\section{SUMMARY AND CONCLUSIONS}

In this research, the behavior of HSCBs reinforced with GFRP bars subjected to bending moment loads was studied using an experimental study and a non-linear 3D finite element model. An experimental study was conducted to study the effect of the different reinforcement two types on HSCBs, the effect of the presence of steel fibers in concrete reinforced with GFRP bars beams, and for the verification from a non-linear 3D finite element model. The non-linear finite element model was constructed in ANSYS using solid elements capable of simulating cracking behavior using the smeared crack approach. The model was verified by coring its results to laboratory experiments. The model was analyzed under vertical load with varying compressive strengths of concrete and GFRP bars ratio of different proportions to study the structural behavior of the beam and the GFRP bars ratio on stiffness in each case. The analysis showed that the capacity of the beam in the non-linear analysis was affected by the ratio of the compressive strength of concrete and the GFRP ratio. The conclusions obtained in this study can be summarized in the following points:

1. The behavior of GFRP-reinforced concrete beams was different from the change of strength concrete and GFRP ratio when subjected to a given load;

2. The vertical stiffness for the HSCBs reinforced GFRP bars and the HSCBs containing $1.0 \%$ of steel fiber reinforced GFRP bars reached about $28.3 \%$ and $37.7 \%$ of the stiffness for the HSCBs reinforced steel bars respectively.

3. The addition of steel fibers of $1 \%$ increases the concrete strength of up to $9.8 \%$ and increases the vertical stiffness of the HSCBs reinforced with GFRB bars with about $33 \%$.

4. The HSC corresponds to the high tensile strength for GFRP bars. Thus, the use of GFRP bars in HSCBs has physical significance as the entire concrete section exposed to flexure bending load, is used.

5. In case of using a GFRP ratios up to $0.5 \%$ with $\mathrm{HSC}$ equal to or more than $60 \mathrm{MPa}$, the rupture of the GFRP bars occurs before crushing in the concrete;

6. The replacement of steel reinforcement with GFRP bars accelerates the appearance of the initial cracks, increases the failure load and a noticeably increase the deflections up to twice those obtained in case of using HSCBs reinforced steel bars.

7. The spread of cracks and their widening in the beams reinforced with GFRP bars decreases with the increase of the GFRP bars ratio in the concrete section exposed to flexure bending load;

8. The maximum failure load of the HSCBs significantly increases with the increase of the GFRP bars more than $0.5 \%$

9. The increase rate in the failure load of concrete beams of strength equal to or greater than 90 reinforced with a ratio equal to or greater than $1.26 \%$ of the GFRP bars, is obvious and significant; 


\section{BEHAVIOR OF HIGH STRENGTH CONCRETE BEAMS REINFORCED WITH (GFRP) BARS}

10. A finite element model with ANSYS program for theoretical analysis is developed to study the behavior of high strength concrete beams reinforced GFRP bars concrete under flexural loads;An agreement has been obtained between experimental results and finite element analysis.

\section{REFERENCES}

[1] Canadian Standards Association (CSA), parking structures (CAN/CSA413-07). 2007.

[2] ACI Committee 440.3R-04, Guide Test Methods for Fiber-ReinforcedPolymers (FRPs) for Reinforcing orStrengthening Concrete Structures Reported by ACI Committee 440. .

[3] S. B. Patil and G. S. Manjunatha, "Experimental study on bond strength of GFRP bars" Mater. Today Proc., vol. 21, pp. 1044-1049, 2020, doi: 10.1016/j.matpr.2020.01.003.

[4] Y. Chen, J. F. Davalos, I. Ray, and H. Y. Kim, "Accelerated aging tests for evaluations of durability performance of FRP reinforcing bars for concrete structures," Compos. Struct., vol. 78, no. 1, pp. 101-111, 2007, doi: 10.1016/j.compstruct.2005.08.015.

[5] D. Szczech and R. Kotynia, "Beam bond tests of GFRP and steel reinforcement to concrete," Arch. Civ. Eng., vol. 64, no. 4, pp. 243-256, 2018, doi: 10.2478/ace-2018-0072.

[6] H. Huang, Y. Yuan, W. Zhang, R. Hao, and J. Zeng, "Bond properties between GFRP bars and hybrid fiberreinforced concrete containing three types of artificial fibers," Constr. Build. Mater., vol. 250, p. 118857, 2020, doi: 10.1016/j.conbuildmat.2020.118857.

[7] M. Parvizi, M. Noël, J. Vasquez, A. Rios, and M. González, “Assessing the bond strength of Glass Fiber Reinforced Polymer (GFRP) bars in Portland Cement Concrete fabricated with seawater through pullout tests," Constr. Build. Mater., vol. 263, p. 120952, 2020, doi: 10.1016/j.conbuildmat.2020.120952.

[8] A. El-Nemr, E. A. Ahmed, A. El-Safty, and B. Benmokrane, "Evaluation of the flexural strength and serviceability of concrete beams reinforced with different types of GFRP bars," Eng. Struct., vol. 173, no. June, pp. 606-619, 2018, doi: 10.1016/j.engstruct.2018.06.089.

[9] B. Basaran and I. Kalkan, "Development length and bond strength equations for FRP bars embedded in concrete," Compos. Struct., vol. 251, no. February, 2020, doi: 10.1016/j.compstruct.2020.112662.

[10] S. Awad-Allah, "Feasibility of Using GFRP Bars as Reinforcement for Reinforced concrete elements," AlAzhar University, 2018.

[11] R. Qin, A. Zhou, and D. Lau, "Effect of reinforcement ratio on the flexural performance of hybrid FRP reinforced concrete beams," Compos. Part B Eng., vol. 108, pp. 200-209, 2017, doi: 10.1016/j.compositesb.2016.09.054.

[12] V. Gribniak, A. Pérez Caldentey, G. Kaklauskas, A. Rimkus, and A. Sokolov, "Effect of arrangement of tensile reinforcement on flexural stiffness and cracking," Eng. Struct., vol. 124, pp. 418-428, 2016, doi: 10.1016/j.engstruct.2016.06.026.

[13] M. Krall and M. A. Polak, "Concrete beams with different arrangements of GFRP flexural and shear reinforcement,” Eng. Struct., vol. 198, no. July 2018, 2019, doi: 10.1016/j.engstruct.2019.109333.

[14] W. rui Yang, X. jun He, and L. Dai, "Damage behaviour of concrete beams reinforced with GFRP bars," Compos. Struct., vol. 161, pp. 173-186, 2017, doi: 10.1016/j.compstruct.2016.11.041.

[15] M. El-Mogy, A. El-Ragaby, and E. El-Salakawy, Behavior of continuous concrete beams reinforced with FRP bars. 2011.

[16] M. Elchalakani, G. Ma, F. Aslani, and W. Duan, "Design of GFRP-reinforced rectangular concrete columns under eccentric axial loading,” Mag. Concr. Res., vol. 69, no. 17, 2017, doi: 10.1680/jmacr.16.00437.

[17] S. A. Ashour, F. F. Wafa, and M. I. Kamal, "Effect of the concrete compressive strength and tensile reinforcement ratio on the flexural behavior of fibrous concrete beams," Eng. Struct., vol. 22, no. 9, pp. 1145-1158, 2000, doi: 10.1016/S0141-0296(99)00052-8. 
[18] P. S. Song and S. Hwang, "Mechanical properties of high-strength steel fiber-reinforced concrete," Constr. Build. Mater., vol. 18, no. 9, pp. 669-673, 2004, doi: 10.1016/j.conbuildmat.2004.04.027.

[19] T. P. C. for preparation of E. Code, "Egyptian Code of Practice for The Use of Fiber Reinforced Polymer (FRP) In The Construction Fields." 2005.

[20] ANSYS.Ins, “ANSYS User Manual.” SAS IP, U.S.A., 2014. 